\title{
A ilusão real: \\ uma entrevista com Ken Jacobs ${ }^{1}$
}

\author{
The real illusion: \\ an interview with Ken Jacobs
}

\section{Entrevista por Rodrigo Sombra}

Professor adjunto do curso de Audiovisual da Universidade Federal do Mato Grosso do Sul (UFMS). Doutor em Comunicação pelo programa de Comunicação e Cultura da Universidade Federal do Rio de Janeiro (UFRJ). Realizou seu doutorado-sanduíche na New York University, como bolsista da CAPES. Mestre em Estudos de Cinema pela San Francisco State University (SFSU), EUA.

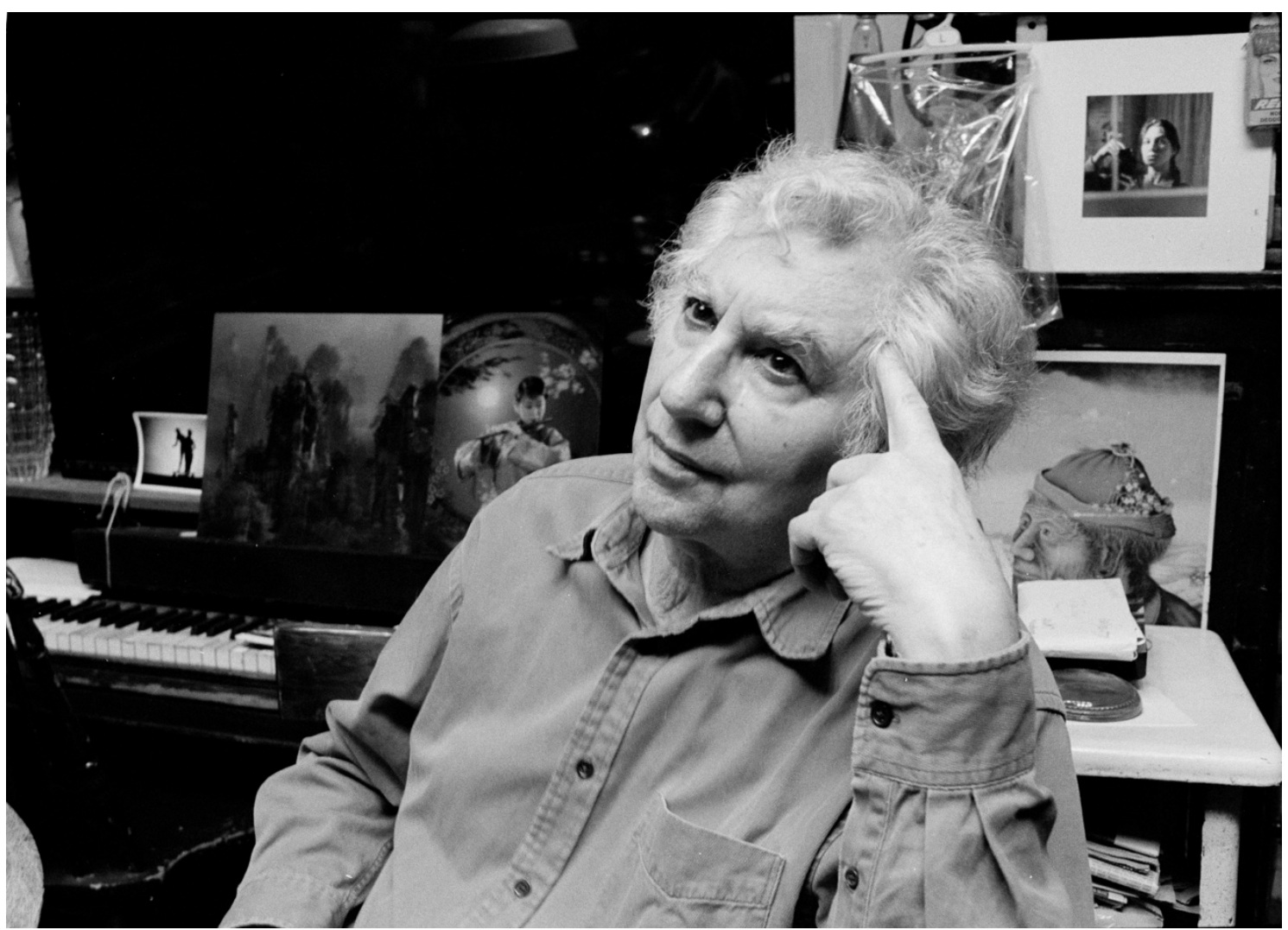

Ken Jacobs por Rodrigo Sombra (C)

${ }^{1} \mathrm{O}$ presente trabalho foi realizado com apoio da Coordenação de Aperfeiçoamento de Pessoal de Nível Superior - Brasil (CAPES).

Dossiê A Música e suas Determinações Materiais - https://revistaecopos.eco.ufrj.br/ 


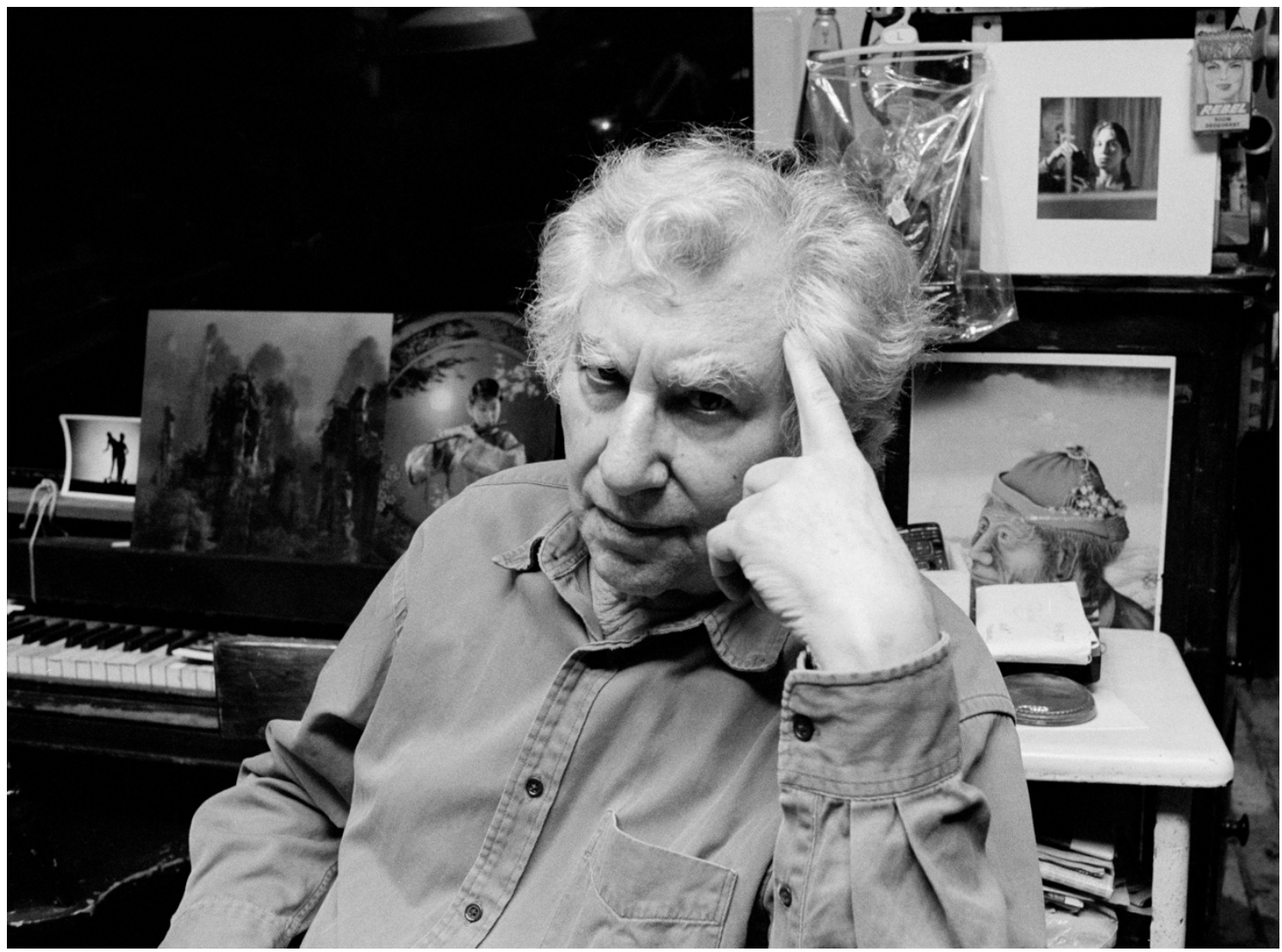

Ken Jacobs por Rodrigo Sombra (C)

“Quarto andar, quarto andar!”, berra Ken Jacobs ao interfone. Figura básica na história do cinema experimental americano, Jacobs vive há décadas no mesmo edifício ao sul de Manhattan, o mesmo onde filmou Nissan Ariana Window (1969) e me receberia numa tarde de inverno para uma entrevista. Vencidos os degraus, ele encontra-me na soleira e me conduz porta adentro. Caminhar por seu apartamento é percorrer um labirinto de prateleiras apinhadas de caixas, imagens, livros, brinquedos e traquitanas de todo tipo. Uma vez ali, é inevitável o risco de esbarrar e pôr a perder algum item daquele gabinete de curiosidades. De fato, muito pouco ali sugere a ideia de casa. É como se Jacobs e sua esposa Flo vivessem mais bem num arquivo, um armazém caótico repleto de prateleiras e gaveteiros onde, por um algum capricho, alguém decidiu pôr uma cama.

Estamos em dezembro de 2018 e nada ocupava mais a cabeça do realizador que os encaminhamentos do processo de impeachment de Donald Trump: "Eu estou 
cansado, cansado de esperar esse presidente ir pra cadeia. Ele só se elegeu por meio da falcatrua. É um bandido. Só se tornou presidente pra ganhar mais dinheiro. Lubitsch poderia ter escrito essa história. Ele tinha certo senso de humor”. À época, Jacobs não estava só na esperança pelo impedimento adiante frustrado: "Um final feliz seria ver Trump vestindo um traje da cor do seu cabelo". Laranja, como o uniforme dos presidiários nos Estados Unidos.

Três meses antes, ele apresentara no Museum of the Moving Image (MoME), em Nova York, uma performance com eternalismos e a sua Lanterna Mágica Nervosa, ambos dispositivos de imagens em 3D fabricados artesanalmente pelo cineasta. Sobretudo a Lanterna Mágica, na qual reina a abstração, é evocativa de seus começos como artista. Pintor na juventude, Jacobs enraizou-se no expressionismo abstrato antes de descobrir o cinema. As idas ao MoMA e a outras salas novaiorquinas dedicadas a filmes de vanguarda o conduziriam a abraçar as imagens em movimento, introduzindo-o no convívio de diretores como Jonas Mekas e Stan Brakhage, irmanados naquela que viria a ser a geração heroica do cinema experimental americano. Jacobs foi também um dos parceiros mais importantes de Jack Smith, ícone do underground gay nova-iorquino com quem colaboraria nos filmes Little Stabs at Happiness (1960) e Blonde Cobra (1963).

A iconoclastia trash dos filmes rodados com Smith seria adiante temperada com pesquisas com linguagens proto-cinematográficas, como o teatro de sombras, a lanterna mágica e a estereoscopia. Tais experimentos evidenciam o radical ilusionismo no cerne da sua arte. Neles, Jacobs toma por objeto o funcionamento da visão humana, fabricando aparatos capazes de criar imagens monstruosas, aberrantes, aptas a "enredar a mente em impossibilidades aparentes 2 ".

O cineasta se notabilizou ainda pelas seguidas revisitas ao primeiro cinema, como em Tom Tom the Piper's Son (1969), seu filme mais célebre. De fato, seria nas práticas found-fotage em que o acento político da sua obra se revelaria com máxima força. Suas incursões no arquivo visual do século XX renderiam algumas das mais inquietantes releituras da história americana, de um gesto aparentemente

2 JACOBS, Ken. Texto do encarte do DVD Nervous Magic Lantern: Spiral Nebula (2005). 
elementar, como apresentar takes descartados de uma reportagem de TV sobre o assassinato de Malcolm-X, encontrados ao acaso no lixo, em Perfect Film (1986), a filmes da estatura de Star Spangled to Death (1956-60/2003-2004), onde o pessoal e o coletivo se amalgamam numa tapeçaria de mais de seis horas de duração retrabalhada por Jacobs ao longo de quase meio século.

Nascido em 1933, Jacobs conserva algo da compleição viril da juventude e o chumaço de grossos fios brancos penteados para trás empresta a seu semblante uma agudeza intimidadora. É um tipo irrequieto. Enquanto ouve as perguntas, remexe-se de um lado para ou outro na cadeira. Quando lhe é dada a palavra, uma voz grave faz vibrar o ambiente ao redor. Na entrevista a seguir, ele comenta suas raízes no expressionismo abstrato, as lições do pintor Hans Hofmann, de quem foi aluno, sem esquecer as de Pollock e Joan Mitchell, e rememora também o convívio com Jack Smith. Discorre ainda sobre a oscilação entre militância e escapismo em sua obra, revelando por fim detalhes de uma faceta pouco conhecida de sua trajetória, os mais de 30 anos como professor universitário, quando enredava os alunos num engajamento permanente com o cinema praticado em Hollywood.

\section{Rodrigo Sombra: Há muito você tem denunciado o cinema como um dispositivo a serviço do poder. Em diversas ocasiões, enfatizou o quão manipuladoras, insidiosas, em suma, perigosas, as operações cinematográficas podem ser. E mesmo o quão tirânicas elas são quando a serviço de um sistema cultural como Hollywood. Você parece ter conservado desde sempre uma atitude de suspeição diante do cinema. 0 que está na origem dessa atitude? Quando começou a nutrir esse sentimento?}

Ken Jacobs: Quando fiz 17 anos me tornei suspeito em relação a tudo, tudo. Todas as minhas atitudes políticas remontam aos meus 17 anos.

\section{O que aconteceu nesse período?}

Apenas me tornei alerta. Entendi que as pessoas eram recompensadas com a farsa, que a história americana não era o que se dizia. Eu conversava com a minha avó e ela vez por outra recebia cartas da Europa, enviadas pelos membros sobreviventes

Dossiê A Música e suas Determinações Materiais - https://revistaecopos.eco.ufrj.br/

ISSN 2175-8689 - v. 23, n. 1, 2020

DOI: 10.29146/eco-pos.v23i1.27547 
da nossa família, judeus da Europa oriental. Era chocante. Então, de certa forma, isso foi se desenvolvendo em mim, comecei a entender a esquerda e a direita, do que se tratava aquilo tudo. E eu só me aprofundava nesta atitude, nada era atenuado.

Você é um dos pioneiros do cinema experimental americano. Poderia descrever como era o público, os espectadores, da cena experimental nova-iorquina ao final dos anos 50, início dos anos 60? As sessões no Cinema 16, no Charles Theatre?

O Cinema 16 foi uma coisa maravilhosa que aconteceu, e o MoMA exibia filmes impossíveis. Assistíamos a Lulu. Qual é o nome dela...? Louise Brooks! Louise Brooks naquele filme antigo de Pabst [A Caixa de Pandora, 1929], e aquilo era incrível. Eu via esses filmes aos 17 anos de idade. A minha escola em Williamsburg, no Brooklyn - uma região muito pobre naquela época -, oferecia um ingresso para estudantes que quisessem ir ao museu. Você entrava de graça com ele. A certa altura, o professor me disse: "Pode ficar com o ingresso até que alguém mais peça. Você é o único que usa", então eu ia ao museu todas as semanas. Se eu tivesse 30 centavos guardados, eu ia e voltava do museu. Então era incrível. Era toda uma outra dimensão da realidade. As pessoas eram cultas, elas se sentavam do lado de fora, no jardim do museu [MoMA]. As pessoas eram cultas, os filmes eram inquietantes. Eu vi Ouro e Maldição (1924) lá. Ouro e Maldição, de Stroheim, aos 17 anos! Havia uns poucos filmes americanos bons, mas muito poucos.

Havia também um cinema, um cinema estranho, em Williamsburg, que passava filmes antigos, acho que porque eram baratos. Aquele cinema quase não tinha público, mas exibia coisas como Sonho de uma Noite de Verão (1935), de Max Reinhardt. Eu via coisas maravilhosas lá. Eu sempre tive um interesse por arte, e aquela foi a minha virada para o cinema.

E quando os seus filmes, ou os filmes de Jonas Mekas ou Jack Smith, os membros da então emergente cena do cinema experimental, eram exibidos, como o público reagia? Os espectadores tinham uma atitude reverente diante dos filmes de vocês, como acontece hoje quando eles são vistos?

Dossiê A Música e suas Determinações Materiais - $\underline{\text { https://revistaecopos.eco.ufri.br/ }}$

ISSN 2175-8689 - v. 23, n. 1, 2020

DOI: 10.29146/eco-pos.v23i1.27547 
Jack [Smith] tinha uma abertura muito estreita na alma. Ele amava os filmes que tinha visto quando era criança morando no Meio-Oeste. E estes eram espetáculos estúpidos, coloridos. Ele nunca superou aquilo. Eu acho que às vezes ele podia ver os méritos dos grandes filmes, mas sua necessidade de cinema, seu amor por cinema, permanecia com aqueles outros filmes [vistos na infância], então, na sua própria obra, ele zombava deles e ao mesmo era reverente a eles. Ele amava aquilo tudo. Ele era assim.

\section{Você colaborou com Jack Smith em filmes como Blonde Cobra (1963) e Star Spangled to Death (1956-60/2003-2004), mas sabe-se que houve um momento em que vocês se afastaram, que a amizade e a parceria de vocês foram interrompidas para sempre.} Quais os efeitos mais duradouros da presença de Jack Smith na sua obra e na sua vida?

Na minha vida, nenhum. Blonde Cobra, de fato, eu não filmei. Eu filmei Star Spangled to Death e quem me ajudava de vez em quando era Bob Fleischner. Quando terminamos de rodar Star Spangled, Bob e Jack começaram a filmar Blonde Cobra em segredo, mas nenhum dos dois sabia o que fazer com o material que eles haviam filmado. Eles não tinham ideia de como organizá-lo. Eu olhei aquilo e disse: "há um filme aqui". Bob me deu tudo o que eles tinham filmado e, mais adiante, eu gravei as falas de Jack e as montei para criar Blonde Cobra.

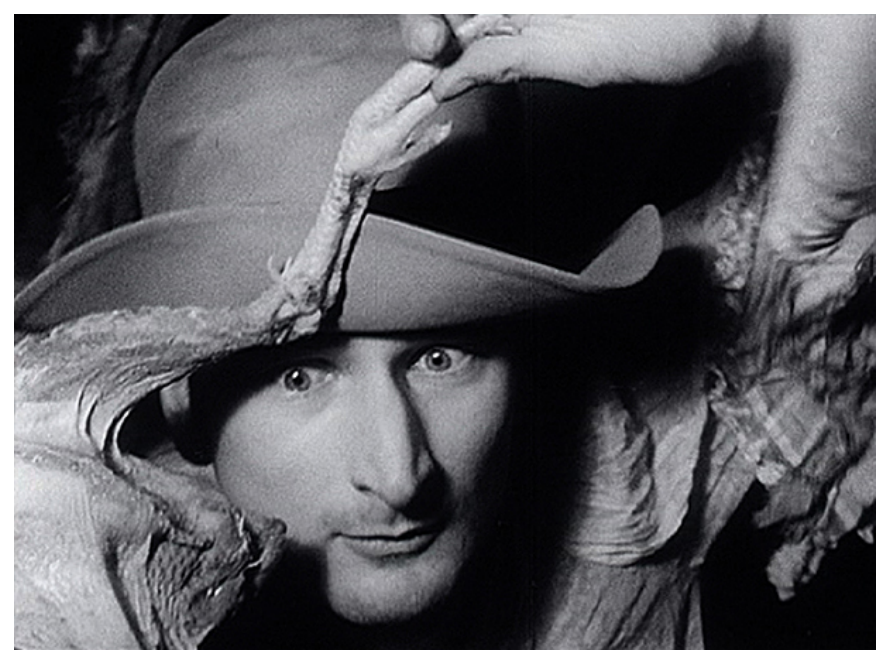

Blonde Cobra (1963) 


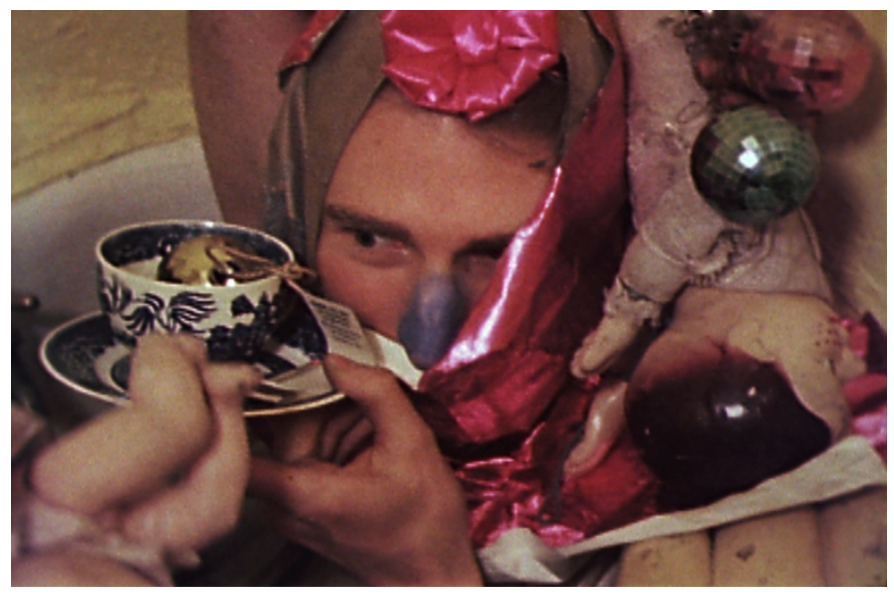

Little Stabs at Happiness (1960)

Parte do seu trabalho envolve materiais descartados: restos, trapos, lixo. De onde vem esse interesse?

Isso que você chama de lixo é a história. É a história mais profunda, a história descartada, e isso me atrai.

Flaubert dizia que há uma "densidade moral a ser encontrada em certas formas de feiura".

Isso é muito bom.

Que tipo de moralidade está envolvida no seu engajamento com os restos, com os materiais descartados?

Outra palavra para esses materiais descartados é "detrito". Às vezes, uma cesta de lixo convida você a jogar os seus detritos dentro dela. Eu acho que isso [a moralidade] é uma reação ao holocausto. Sim, a questão dos judeus. E eu não sou religioso de jeito nenhum. De jeito nenhum. Eu sou muito anti-religião, muito anti qualquer cosmologia fixa. 0 nascimento virginal é uma vergonha. É a coisa mais idiota do mundo. Mas há os fatos históricos. As pessoas experimentaram certas coisas. A minha avó estava experimentando no Brooklyn o que estava acontecendo com seus parentes na Europa. 


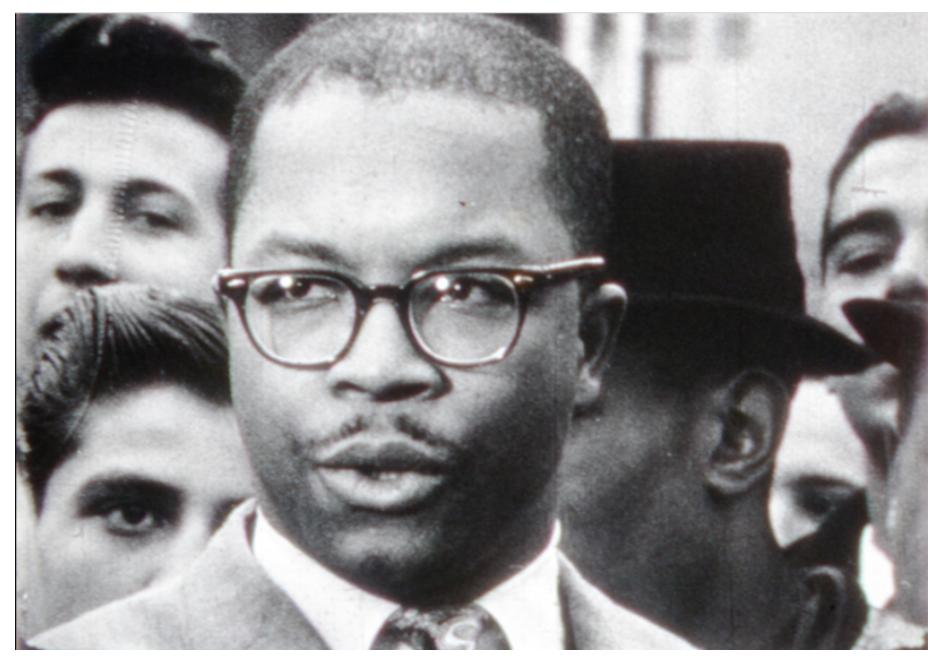

Perfect Film (1986)

Você certa vez disse que a sua contribuição estaria em criar "um expressionismo abstrato fora-de-mercado, retomando lições Marey-Muybridge de Hans Hofmann". Hofmann foi, de fato, seu professor, mas queria que você comentasse o lugar de Eadweard Muybridge e Étienne-Jules Marey na sua formação. Eram como mentores imaginários para você?

Não, eles foram professores de verdade. Veja as obras deles, são incríveis. Eles romperam a continuidade da ilusão. Eles queriam reduzir as coisas ao frame. Marey, especialmente...Meu Deus, é simplesmente uma revelação. Todos esses sonhos são frames? Uau, quanta verdade! Hoje as crianças aprendem facilmente no Youtube, mas quando eu era criança você ia ver um filme e você entrava num sonho.

Você podia comentar um pouco mais sobe como assimilou Muybridge e Marey em seu trabalho?

Penso justamente na importância do núcleo, do frame, sabe? A história está muito, muito longe do frame. Outro professor foi a bomba de átomos. Há algo tão profundamente intrínseco à criação, e desta vez não falo do cinema, mas simplesmente da vida poder ser alcançada, e poder ser explodida, e liberar toda aquela energia misteriosa que devastaria cidades...meus Deus. Isso faz com que você se volte pra dentro de si mesmo.

Dossiê A Música e suas Determinações Materiais - https://revistaecopos.eco.ufri.br/ 
Eu amo o cinema, assim como qualquer um. Assisto muitos filmes - hoje na televisão - e, eu lhe digo, são filmes fantásticos. É incrível a maestria com que eles são feitos. Nosso filho [Azazel Jacobs] faz filmes - e eles são bons, mas não é isso o que eu quero fazer. 

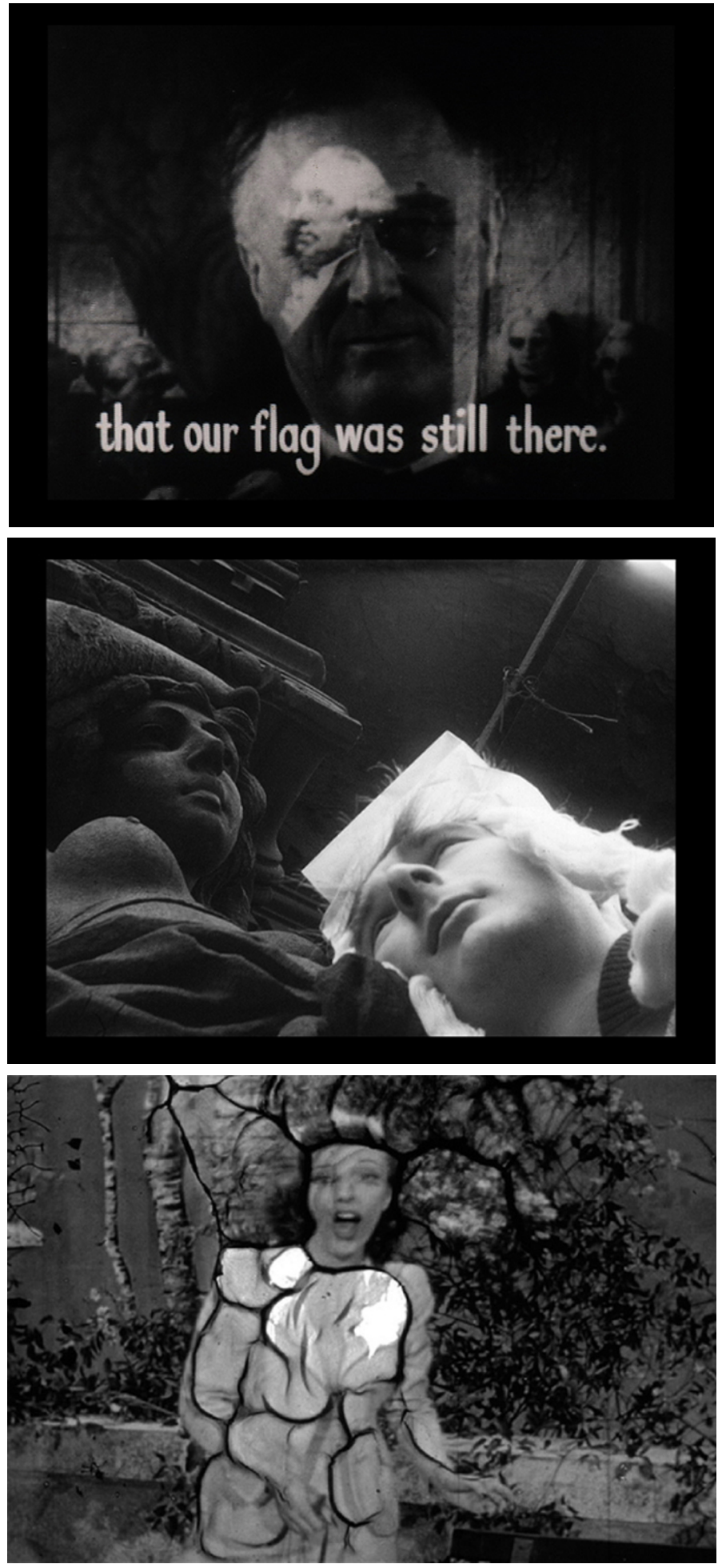

Star Spangled to Death (1956-60/2003-2004)

Dossiê A Música e suas Determinações Materiais - $\underline{\text { https://revistaecopos.eco.ufri.br/ }}$

ISSN 2175-8689 - v. 23, n. 1, 2020

DOI: 10.29146/eco-pos.v23i1.27547 
No livro Film at Wit's End: Eight Avant-Garde Filmmakers (1989), Stan Brakhage afirma: "Ken Jacobs nunca se deu bem com a 'turma das artes' de Nova York. Ele a rejeitava completamente". Você concorda com esta observação? A sua relação com os círculos das artes segue a mesma ainda hoje?

Não, hoje sou mais gentil.

O que mudou?

Já não sou tanto um esnobe anti-esnobes. Sou mais compreensivo. As pessoas têm as suas presunções, e elas precisam delas.

De certa forma, o seu engajamento com dispositivos proto-cinematográficos (teatro de sombras, lanterna mágica, visualidade estereoscópica) já apontava para a ideia de "cinema expandido", para práticas ligadas à imagem em movimento que viriam a ser amplamente acolhidas na arte contemporânea. No entanto, embora suas obras sejam projetadas nas salas de cinemas dos museus, são raras as ocasiões em que elas são exibidas nos espaços expositivos. Por quê? Você acredita haver alguma espécie de resistência institucional ao seu trabalho?

Eu me sentia bem-vindo, mas muitos no público não entendiam o eles que estavam vendo. Eram impacientes e dificilmente se deixavam convencer de que, se dessem algum tempo àquilo algo poderia acontecer. Eu estava usando meios com os quais eles estavam familiarizados - o cinema -, mas não para fazer filmes.

Posso lhe mostrar uma coisa?

[Aceito o convite, interrompemos a entrevista e Jacobs me conduz ao monitor onde trabalha para assistir ao seu mais recente experimento. Intitulado Details of Pollock's White Light, trata-se de um eternalismo aplicado sobre um óleo de Jackson Pollock. "Tem só oito minutos", avisa, antes de apertar PLAY. "E funciona melhor com um olho só", diz, estendendo-me um retângulo de papelão de tamanho pouco maior que um globo ocular. A imagem na tela oscila entre as cores e contrastes entre os brancos e os pretos, desfazendo-se em múltiplas variações espaciais, em sugestões de

Dossiê A Música e suas Determinações Materiais - https://revistaecopos.eco.ufri.br/ 
volume e profundidade antes imperceptíveis, como se a técnica do eternalismo inventada por Jacobs adensasse a materialidade da pintura, a espessura de cada rastro de tinta. Ao fim da projeção, volto-me para o lado e noto Ken e Flo, sua esposa, ambos de pé, ainda fixados no ecrã. Cada um deles leva a mão direita sobre um dos olhos e deixam entrever nos lábios um sorriso. Retornamos enfim à mesa circular no centro do apartamento para retomarmos a conversa, desta vez acompanhados por Flo].

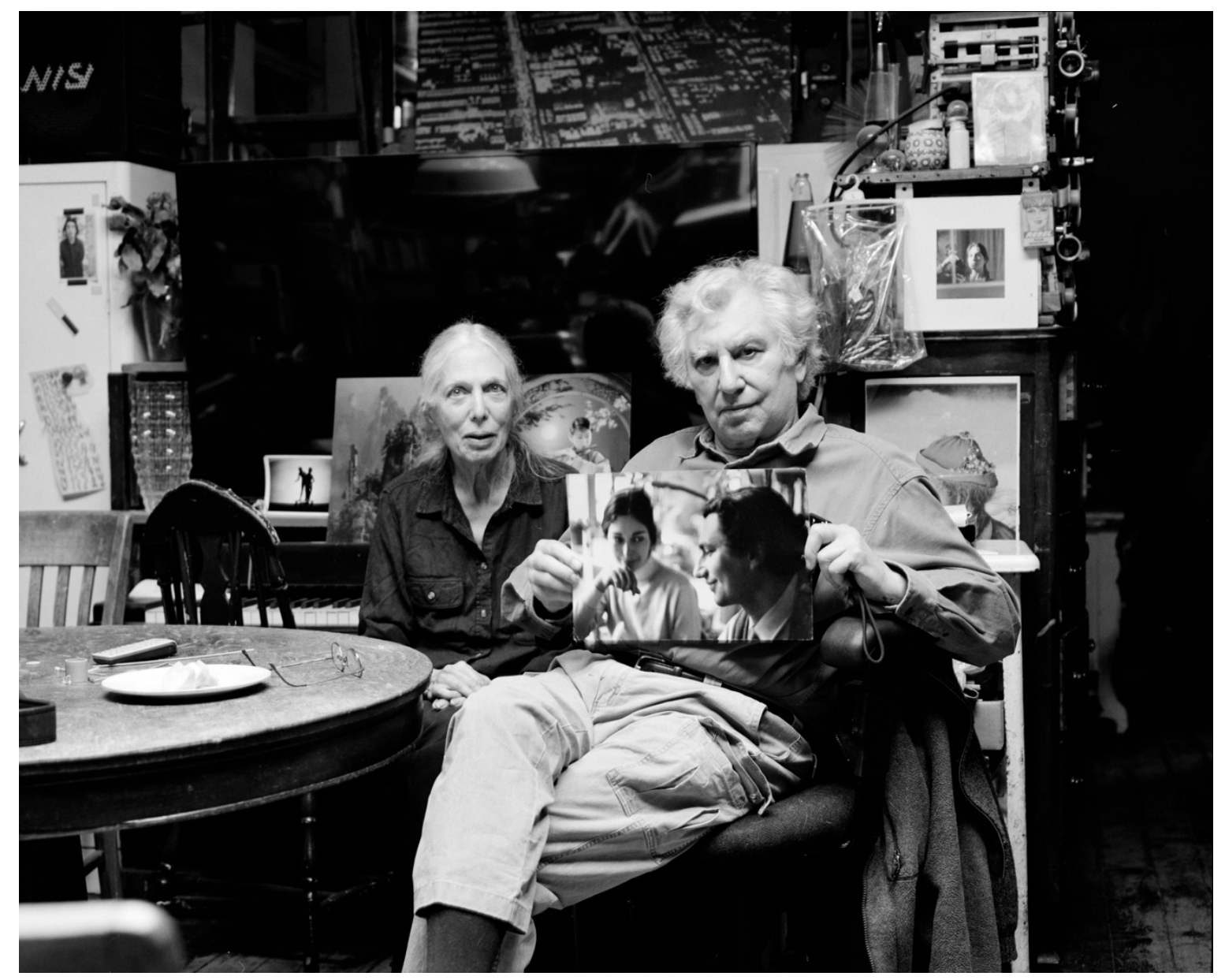

Ken \& Flo Jacobs por Rodrigo Sombra (c

Dossiê A Música e suas Determinações Materiais - $\underline{\text { https://revistaecopos.eco.ufrj.br/ }}$ 


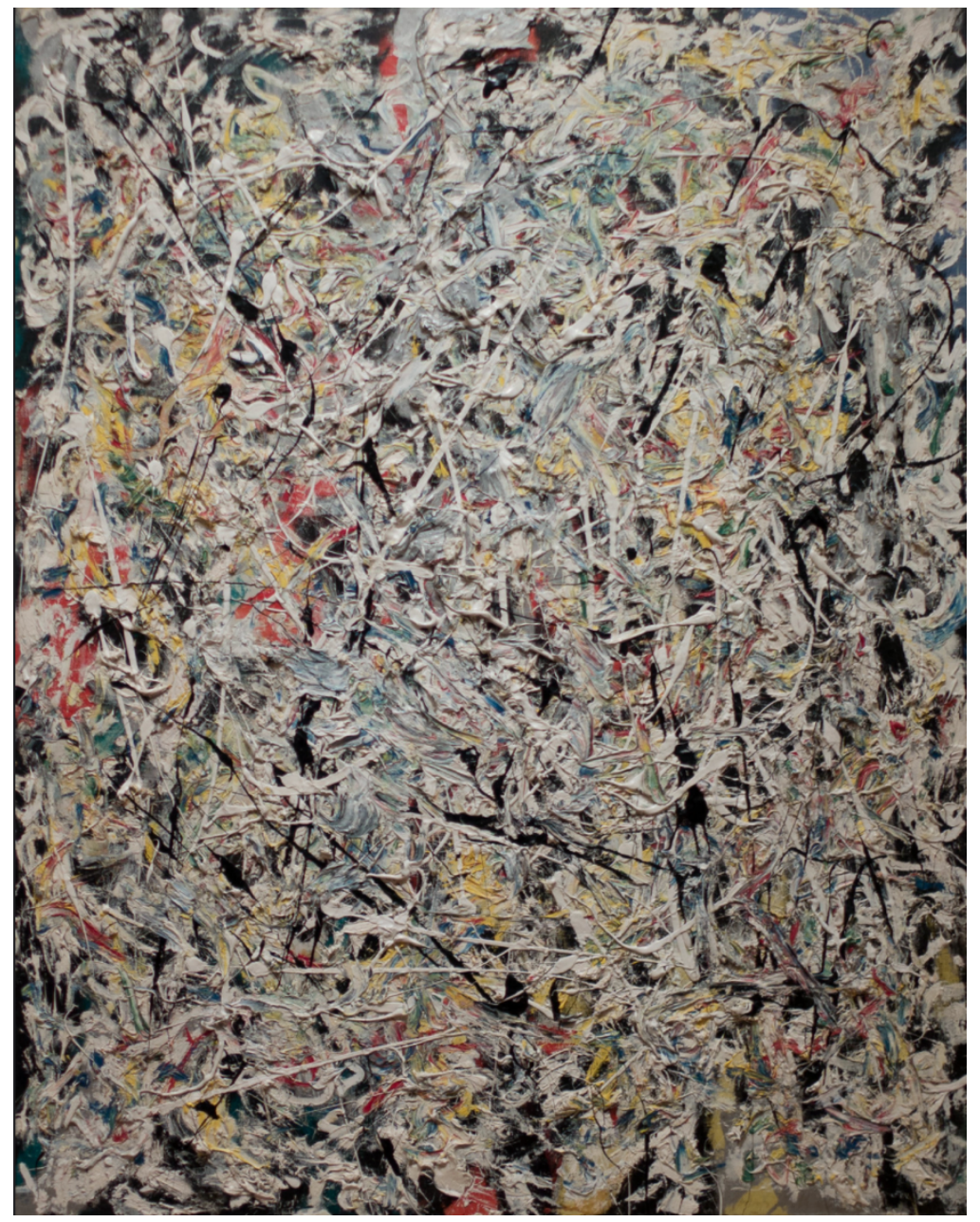

White Light (1954), de Jackson Pollock/Reprodução fotográfica por Sharon Morellus

Você me contou agora há pouco que esteve com Pollock. Como foi o seu encontro com ele?

Ele era tão repulsivo... Andava bêbado, era vulgar, violento. Ele era bem maluco.

\section{Foi um encontro breve?}

Não, não chegamos a nos "encontrar". Eu apenas o observava. Ele era muito repulsivo. Você logo percebia que era melhor ficar longe dele. Havia um bar perto da Hofmann School aonde os artistas iam e eles não permitiam que ele entrasse lá (risos). Ele era maluco.

Dossiê A Música e suas Determinações Materiais - https://revistaecopos.eco.ufrj.br/ 
O que mais me marcou ao assistir a Lanterna Mágica Nervosa, na sua última performance no MoMI (Museum of the Moving Image), foi, ao longo da sessão, entrar num estado de radical curiosidade. Mas aquela era uma curiosidade sempre frustrada. Você me atraía para ver os objetos, os objetos abstratos vistos nas imagens projetadas, e no começo eu tinha apenas um vislumbre daqueles objetos, mas logo a minha visão era convocada a ver mais, a ver o volume deles, a observar todos os seus cantos, a vê-los sob todos os ângulos. No entanto, aquela era uma visão jamais disponível em sua inteireza. Tudo recomeçava de uma hora para outra, havia sempre uma interrupção, o looping era sempre interrompido, os objetos nunca eram vistos por inteiro. Então havia sempre esse intenso jogo entre curiosidade e frustração.

Uma máquina de frustração! Acho que vou batizar o meu próximo trabalho de "Frustration Machine" (risos). Eu projetei essas aqui no museu [estende lâminas com imagens abstratas, o tipo de lâmina projetada através do dispositivo da Lanterna Mágica Nervosa]?

Sim, creio que você as projetou aquele dia.

Eu estou explorando o subconsciente. Efeitos óticos acontecem, as luzes se acendem e se apagam. É um certo tipo de hipnotismo.

Sim. Assistir a Lanterna Mágica Nervosa é como submeter-se a uma possessão, é como ver um espetáculo de assombração.

E perigoso, enlouquecedor. Mas a ideia era que fosse belo. Recentemente, encorajei uns amigos a trazerem seus filhos aqui, porque a experiência me ensinou que as crianças assistem essas coisas falando em voz alta. E elas falam sobre o que veem. É muito interessante. Com frequência, quando vamos ver arte abstrata sofisticada, nos dizem: "Você não deve fazer como no teste de Rorschach, não deve ver coisas que não estão lá, apenas a tinta”. Mas eu descobri que eu gosto demais quando crianças, criancinhas pequenas, falam sobre o que elas veem (risos). Então eu convidei esses amigos a virem aqui em casa com os filhinhos deles (e enquanto eu trabalhava, eu também mostrava a eles o que estava fazendo, pois não queria assustá-los) e uma

Dossiê A Música e suas Determinações Materiais - https://revistaecopos.eco.ufri.br/

ISSN 2175-8689 - v. 23, n. 1, 2020

DOI: 10.29146/eco-pos.v23i1.27547 
hora eu percebi que uma daquelas crianças estava debaixo da minha cadeira desenhando tudo o que via.

Curioso você falar isso, pois Pollock dizia que embora seu trabalho fosse abstrato, havia nele sempre um grau de figuração.

Ken Jacobs: É por isso que considero Joan Mitchell uma artista maior. Quando, ao final da carreira, Pollock abandonou a pintura com respingos, ele se tornou muito figurativo. Começou a pintar faces, e aquilo era terrível. Joan Mitchell sempre falou sobre inspirar-se na natureza, mas ela jamais copiou a natureza. Quando você olha o trabalho dela, o que você vê é a tinta.

Flo Jacobs: Mas não se pode dizer nada diferente a respeito de Pollock.

Ken Jacobs: Ao final, Pollock estava pintando faces.

Flo Jacobs: Mas essa era outra fase da carreira dele.

Ken Jacobs: Mas a tendência esteve sempre lá. Ele resistiu, mas também se deixou levar. Esses caras [os expressionistas abstratos] admiravam muito Picasso. Picasso nunca deixou a figuração. Nem por um momento ele parou de pintar coisas, e não há nenhum problema nisso. Mas a grande descoberta que vejo no que eles estavam fazendo estava em vir a perceber o que apenas a tinta faria. Deixe a tinta ser tinta. Não a deixe evocar ou parecer as coisas do mundo. Deixe-a fazer o que ela pode fazer.

Além disso, Hofmann, em particular, deixava você muito, muito, consciente em relação à profundidade. Valorizo as suas pinturas porque as vejo em suas poderosas sugestões de profundidade. Eu trabalho na ilusão. Ilusão real, que, por estranho que pareça, é mais eficaz para um olho do que para dois. Normalmente, é necessário ter dois olhos para ver a profundidade, mas isto [mostra uma lâmina da Lanterna Mágica Nervosa] é para um olho só. Mas eu me desviei. Afastei-me da pintura... Na verdade, isso [mostra as lâminas] é pintura. Ainda estou pintando, para minha surpresa. Exceto que você não a vê diretamente, você vê a sombra dela.

Outro aspecto que me impressionou muito na Lanterna Mágica Nervosa é que assisti-la é experimentar longas durações, mas estas são continuamente 


\section{ENTREVISTA}

interrompidas. Há o tempo dilatado, a duração, e ao mesmo tempo, com os efeitos da flickagem, as seguidas quebras. É como se você nos lançasse num paradoxo: experimentamos duração e interrupção ao mesmo tempo.

Oh, eu adorei isso que você disse. Você está me deixando muito feliz por ouvir isso! Gosto muito disso que você está dizendo. Veja, você está pegando a estrutura atômica do tempo. Você tem este pedaço de tempo, aquele pedaço de tempo, e este pedaço de tempo, e eles estão entrando em combustão na sua frente.
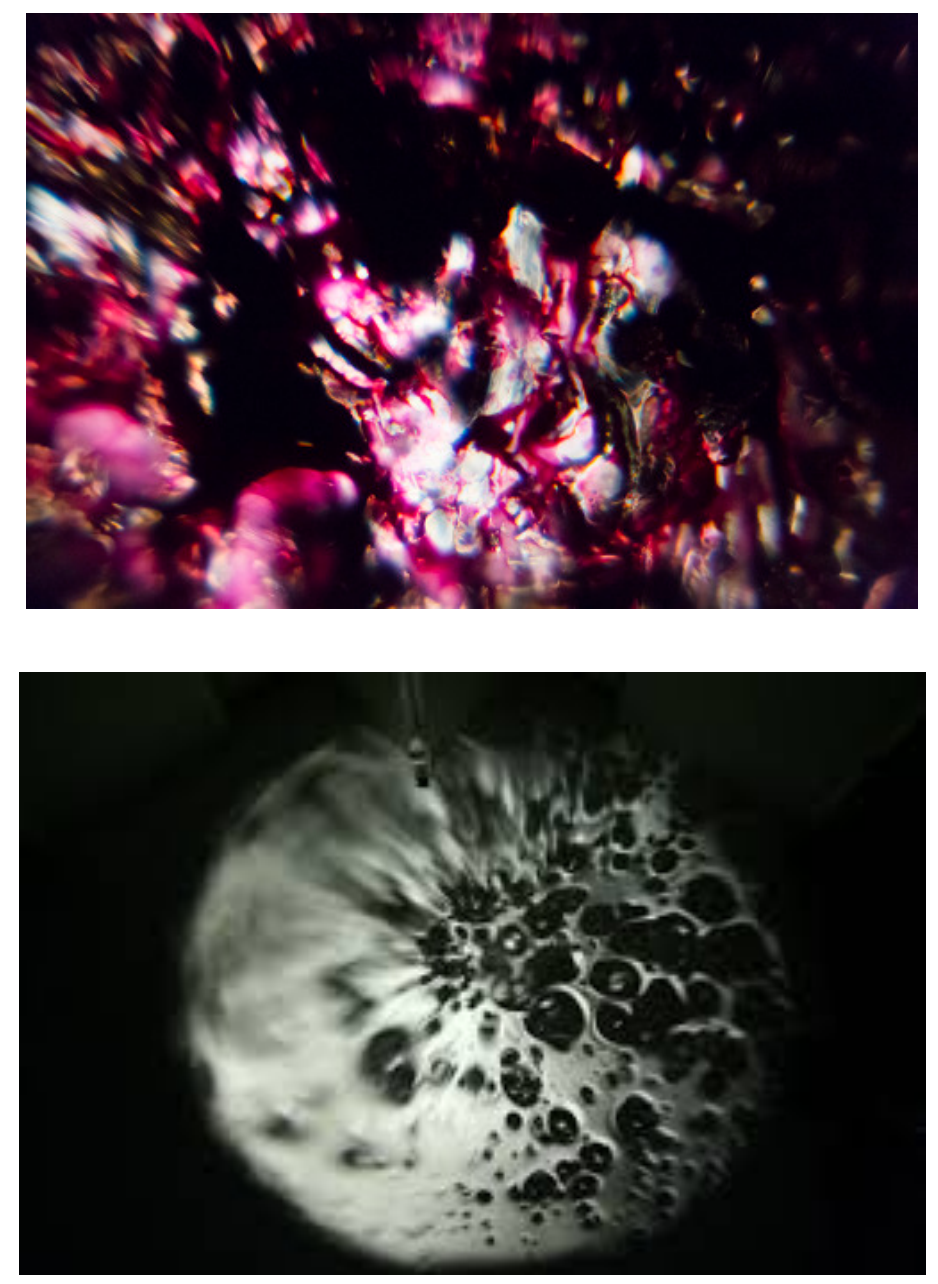

Dossiê A Música e suas Determinações Materiais - https://revistaecopos.eco.ufri.br/ 


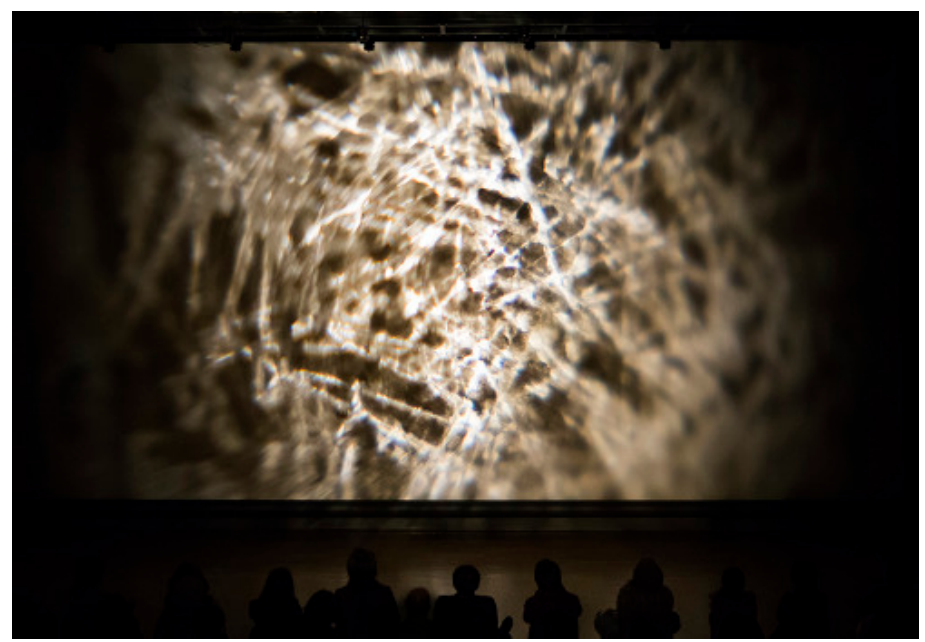

Lanterna Mágica Nervosa

Tom Tom the piper's son (1969-71) é a sua obra mais conhecida. O filme recebeu considerável atenção crítica, e boa parte do que se publica sobre ele tende a enfatizar os movimentos analíticos empenhados em Tom Tom, a associá-lo a uma espécie de impulso arqueológico. Eu o revi recentemente, pela primeira vez no cinema, e o que me chamou a atenção foram menos os procedimentos de análise visual que costumam ser destacados e sim, na falta de palavra melhor, um profundo amor, uma profunda devoção por aquelas imagens. Gostaria de ouvir um pouco mais sobre o que, especificamente, naquele filme de 1905, rodado por Billy Bitzer, lhe atraiu. $\mathrm{O}$ que fez com que você se apropriasse dele para criar Tom Tom?

Era isso mesmo. Ele foi feito a partir da minha fascinação. Eu amava as mulheres no filme. Amava seus pescoços. Eu amava aquele filme e eu não conseguia abrir mão dele desde que o vi. Nós continuamos trabalhando com ele em performances ao vivo por anos a fio. Foram 25 anos viajando com ele, usando velhos projetores analíticos; mais adiante, pude encontrar outras formas de exibi-lo um frame de cada vez. Usávamos dois projetores lado a lado e duas cópias do mesmo filme. Projetávamos um ou dois frames - às vezes mais - fora de sincronia um com o outro, então as similaridades e diferenças resultavam em todo tipo de espaços estranhos. Aberrações. Espaços estranhos, loucos - louco é a palavra, não? Espaços loucos. E eles eram bonitos de se explorar, maravilhosos de se explorar. 
Há quem afirme que o aparecimento de Tom Tom the piper's son ajudou a estimular toda uma nova apreciação do primeiro cinema. De fato, o filme acena à riqueza plástica dos começos do cinema, às suas origens como uma forma de arte. Por outro lado, ele me arrebata como uma experiência de futuridade. Aquele é um filme de 1969 que, em certo sentido, prefigura as nossas atuais relações com as imagens, que antecipa muitos de nossos hábitos na era digital. Congelar a imagem, reenquadrála, dar zoom, acelerar e desacelerar um filme, ir e voltar no tempo de sua duração, mexer com a imagem a ponto de desfigurá-la, de torná-la uma massa de grãos, pura abstração: tudo isso já está lá no seu filme.

Eu acho que sim. Mas é uma experiência real de investigação do cinema. A imagem do cinema e as coisas que formam esta imagem. Esses pequenos pontinhos e espaços que formam a imagem. As partículas subatômicas de uma imagem visual. A princípio, eu assisti ao filme [de Bitzer] algumas vezes assim que ele chegou às minhas mãos. Ele havia sido recuperado da Biblioteca do Congresso. Nos anos 50, 60 , alguém foi lá e refotografou esses filmes antigos, e eles se tornaram disponíveis. E eu comecei a ensinar na Saint John's University. Uma universidade católica grande, com cerca de 300 alunos, acho. As mulheres todas usando meias 3/4. Eles eram tão oprimidos... Eram tão certinhos, e eu comecei a mostrá-los todas aquelas coisas impróprias (risos). Eu gostava de fazer isso. Então, aqueles filmes ficaram disponíveis e eu tinha um orçamento da universidade, e com este orçamento eu podia alugá-los e assisti-los. A maior parte deles não valia nada, mas aquele era incrível. Era apenas uma explosão. Eu não conseguia acompanhar a história! Eu não conseguia ver direito quem era quem naquela massa de pessoas, não conseguia distingui-las como indivíduos. E eu nunca cheguei a ver o porco que era roubado! Aquilo tudo era fascinante.

Dossiê A Música e suas Determinações Materiais - https://revistaecopos.eco.ufri.br/

ISSN 2175-8689 - v. 23, n. 1, 2020

DOI: 10.29146/eco-pos.v23i1.27547 


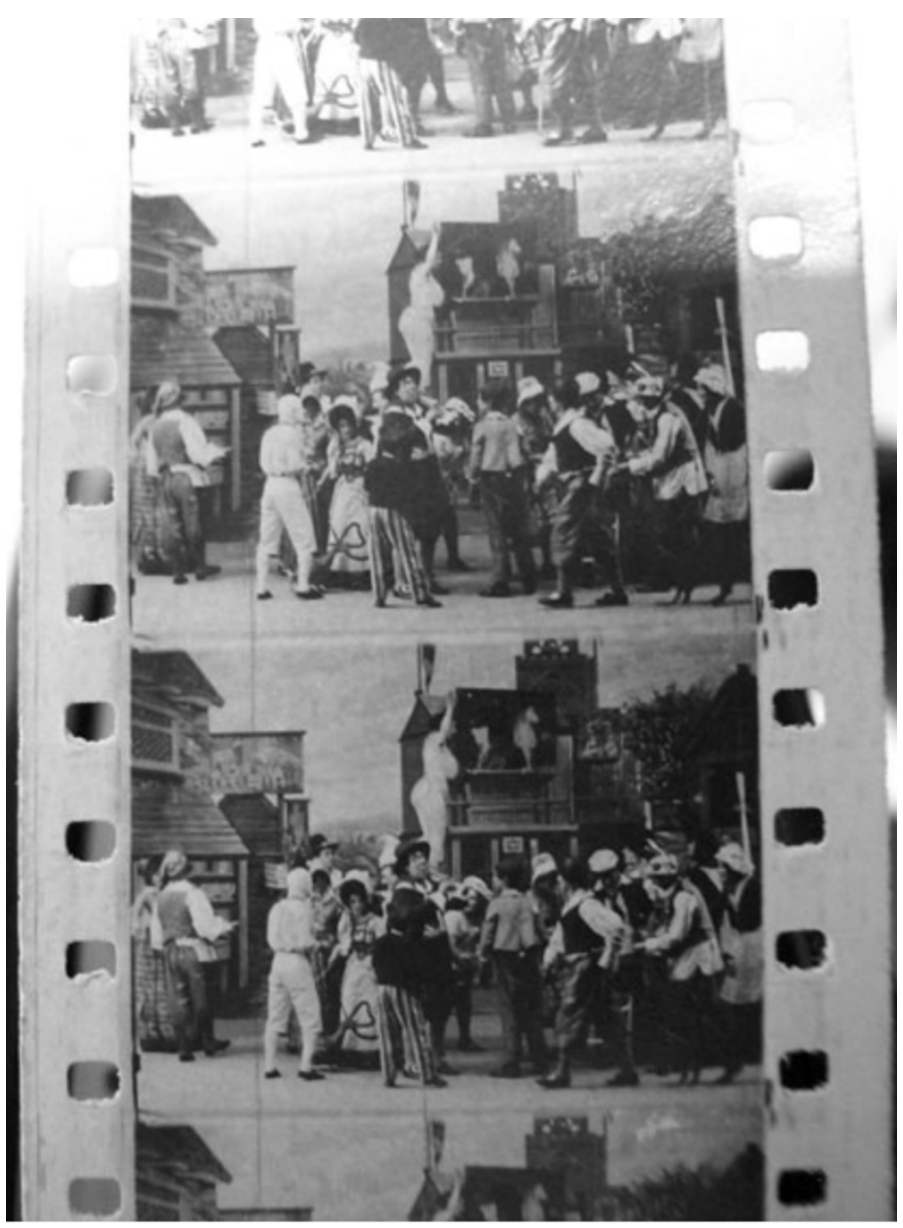

Tom Tom the piper's son (1969-1971)

Tom Tom the piper's son implica também uma pedagogia do olhar. No início, você mostra todo o filme de Bitzer, depois você o decompõe e o analisa, faz o seu experimento, e ao final torna a nos mostrar o filme original outra vez, do início ao fim.

Sim, é isso. Mas, agora, você o vê diferentemente.

Já no experimento com Pollock que você me apresentou há pouco, você mostra os "frames" que está usando. Por que é importante para você essa demonstração dos materiais, dos procedimentos?

Ken Jacobs: Eu estou levando Pollock para um passeio. A pintura é fantástica. Ele não está pintando rostos aqui. Ele está derramando tubos de tinta. Aquela é uma

Dossiê A Música e suas Determinações Materiais - https://revistaecopos.eco.ufrj.br/ 
pintura realmente incrível, então eu preciso zombar desse ponto de partida, sabe? Estou fazendo uma releitura de Pollock, uma releitura cinematográfica de Pollock, e ele não gostaria disso. Não creio que ele fosse gostar. Não creio que Joan Mitchell gostaria do que eu faço com a obra dela. Mas é uma indignidade muito respeitosa. Estou trabalhando em cima deles.

Flo Jacobs: Eu gostaria de pontuar o quanto disso vem de Hofmann. A ideia de mostrar a fonte, de fazer uma versão daquela obra e, então, observá-la outra vez.

Ken Jacobs: Boa questão... Não sei se consigo responder a isso. Uma das coisas extraordinárias de estudar com Hofmann era que as pessoas pintavam trabalhos muito abstratos, ou desenhos muito abstratos, mas havia sempre um modelo. Havia um modelo sustentando uma pose por às vezes uma ou duas semanas. Nenhum modelo era escolhido pela sua beleza, por sustentar uma pose graciosa. Eles costumavam ser modelos pesados. Havia neles apenas um senso de peso, gravidade, e os trabalhos partiam disso. Ninguém estava desenhando para criar semelhanças. Eu não acho que você poderia dizer, uma vez que a obra estivesse pronta, que ela partia de um modelo. Mas elas eram feitas a partir de um modelo. E Hofmann lhe criticaria muito se o modelo não tivesse sido suficientemente absorvido, se, quaisquer que fossem os desvios feitos no seu trabalho, eles não fossem baseados na realidade do modelo sentado no espaço. Era muito confuso. Eu escrevi algo a respeito disso ${ }^{3}$.

Então tinha a ver com isso, com o modelo ali sentado, mas você estava atrás de uma outra coisa. Você estava fazendo um desenho, que vai ser o modelo, essa verdade que você descobriu sobre o modelo sentado numa cadeira, sentado no espaço, e, no entanto, ao mesmo tempo, não era uma semelhança. Era algo que você estava tirando, algo que você extraía dele.

Flo Jacobs: Eu talvez tenha uma resposta. Talvez seja uma evidência aquilo que Hofmann fazia vocês verem. Uma evidência e o que vem dela, o que você faz a partir dela.

3 Jacobs se refere ao ensaio "Huge churning vistas", disponível aqui: https://www.kenjacobsgallery.com/talks-interviews]

Dossiê A Música e suas Determinações Materiais - https://revistaecopos.eco.ufrj.br/

ISSN 2175-8689 - v. 23, n. 1, 2020

DOI: 10.29146/eco-pos.v23i1.27547 
Ken Jacobs: Sabe, eu acho que o que era importante para ele era a gravidade. Nós estamos sempre em um mundo de gravidade e nunca o deixamos nem por um momento sequer. Ela cumpre um papel enorme nas nossas vidas, um papel ao qual nos acostumamos desde a infância. Não percebemos que a gravidade está em ação [ergue uma colher e deixa-a cair sobre a mesa]. Tudo está sendo puxado para o centro da Terra. Não existe um chão de verdade, mas há o centro da Terra. Esta é a realidade. Penso na imagem do crucifixo, um homem suspenso naquela coisa. A suspensão é uma tortura porque não permite que ele sucumba à gravidade. Ele não pode ir na direção em que a gravidade está puxando.

\section{Esse é um princípio formal muito interessante: a gravidade.}

Meu Deus, este é o princípio. Então você tinha que pensar nessas coisas. Mesmo quando não falava sobre elas, você as punha em algum lugar na sua cabeça onde você tinha que confrontar essas realidades.

Você costuma se referir ao cinema como uma "forma de pensamento". Em que sentido o cinema "pensa"?

A linguagem nos permite formular as ideias que passamos uns para os outros. Mas a mente é capaz de todas as formas de pensamento. Músicos pensam com o som. É muito mais abstrato aonde eles chegam. Eles estão pensando em som. Outro dia eu estava ouvindo Beethoven e aquilo simplesmente me arrebatou. 0 pensamento que existia há um par de séculos, quem poderia operar melhor nesse domínio? Sim, é uma forma de pensamento.

Numa entrevista no início dos anos 1990, ao comentar Nissan Ariana Window (1969), você diz: "Uma das coisas que eram importantes para mim ao fazer este filme, assim como outros feitos àquela época, era criar ilhas de sanidade. Não queria fazer filmes anti-guerra que seriam tão febris quanto a própria guerra, mas criar ilhas de calma, serenidade, sanidade". Você nutre sentimento parecido hoje em dia? Que tipo de resposta o nosso tempo lhe provoca?

Dossiê A Música e suas Determinações Materiais - https://revistaecopos.eco.ufrj.br/

ISSN 2175-8689 - v. 23, n. 1, 2020

DOI: 10.29146/eco-pos.v23i1.27547 
Estamos em um momento maluco. Os republicanos perderam a cabeça. Eles trabalham para os muito ricos. Muitos democratas trabalham para os muito ricos. Vivemos numa plutocracia, vocês [brasileiros] vivem num estado fascista a partir de agora, então as regras não estão sendo mais seguidas. As regras foram descartadas. Trata-se de guerra, poder, propriedade.

Os EUA, que sempre foram grotescamente brutais, agora correm o risco de perder até mesmo a simpatia que tornou a vida aprazível aqui para muitas pessoas. Pessoas em circunstâncias excepcionais, pessoas que não são brutalmente pobres, nem doentes. Você anda pelas ruas agora e vê tantos mendigos implorando por dinheiro. Acho que não era assim há 10, 15 anos. E os EUA estão em guerra, os EUA estão sempre em guerra...

Mas o que eu ia dizendo...? Ah, as ilhas de sanidade! As ilhas de sanidade são muito necessárias. Eu creio que Matisse tinha essa ideia também, de que você poderia olhar para as suas pinturas e se esquecer do mundo ao seu redor. Picasso não lhe deixa esquecer o mundo ao seu redor. E eu acho que era um mérito dele ele não poder esquecer. Picasso podia presenciar a brutalidade do mundo, enquanto Matisse escapava dela. Mas acho que eu também estou escapando. Na maioria dos meus trabalhos eu também escapo. Mas eu faço muitas obras, então coisas como Capitalism Child Labor (2006) reconhecem o que está acontecendo. Você chegou a ver Seeking the Monkey King (2011)? Está no meu site, de graça. Nesse tipo de trabalho eu me permito fazer as minhas "obras Matisse". Mas, veja, essas ilhas de sanidade, elas são criminosas. Quem poderia realmente negligenciar o que está acontecendo? É horrendo. 


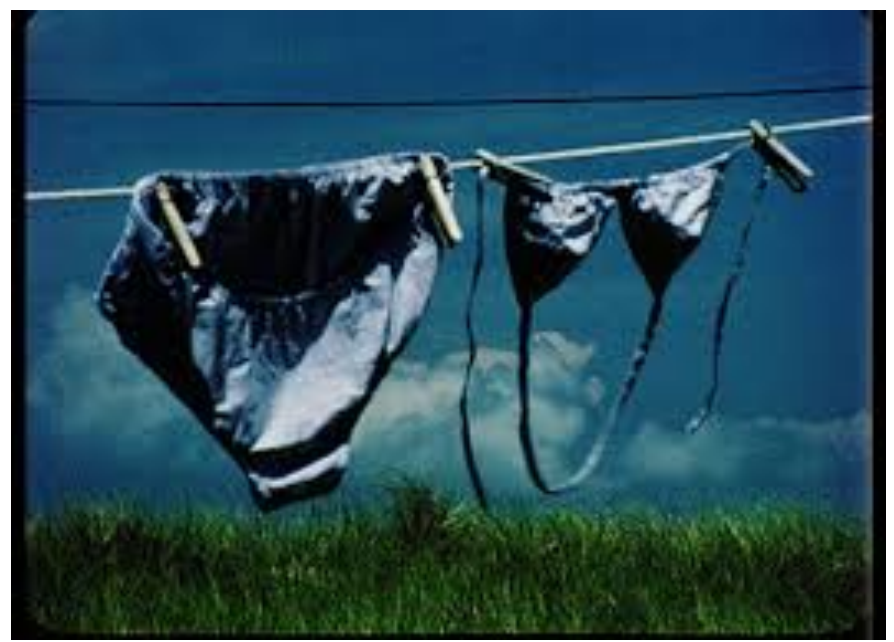

Nissan Ariana Window (1969)

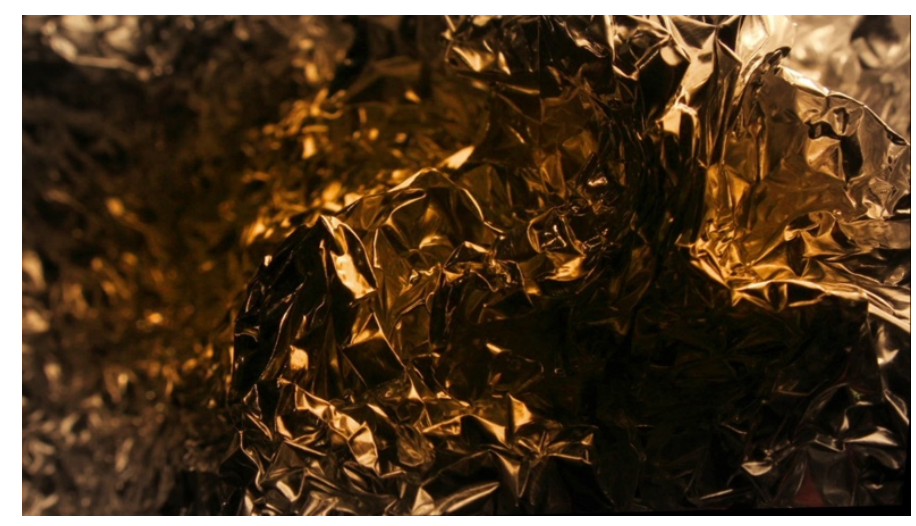

Seeking the Monkey King (2011)

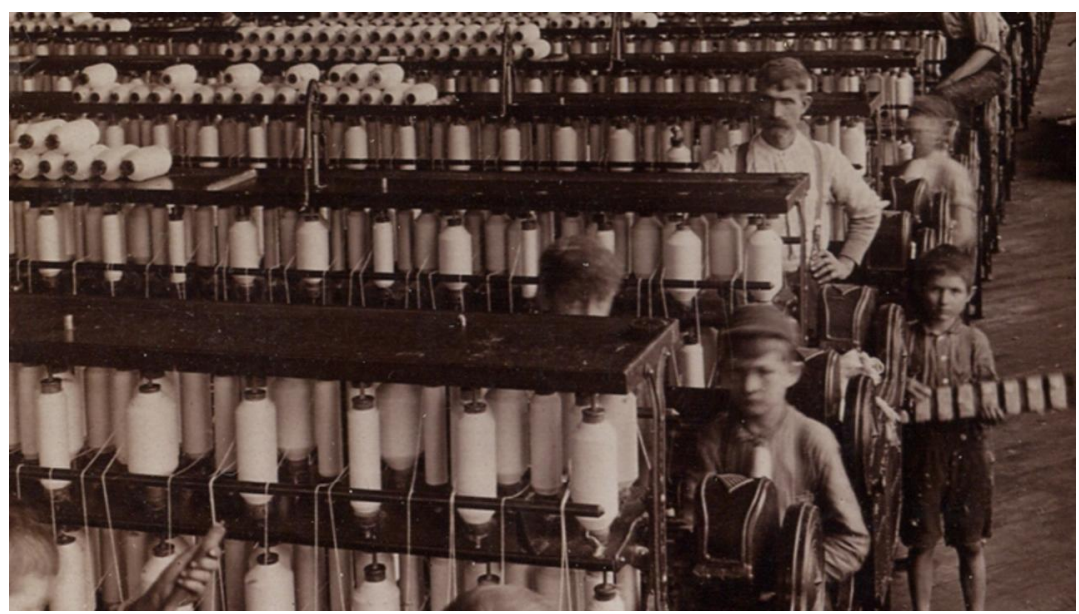

Capitalism Child Labor (2006)

Dossiê A Música e suas Determinações Materiais - https://revistaecopos.eco.ufrj.br/ 
Em sua última performance no Museum of the Moving Image, você apresentou um eternalismo inspirado na ativista Patricia Okoumou, que um mês antes havia escalado os pés da Estátua da Liberdade para protestar contra a prisão de crianças imigrantes pelo governo Trump. 0 que naquele gesto lhe motivou a homenageá-la?

Eu só posso lhe dizer que por absoluta necessidade. Enquanto eu fazia o filme ela fez a escalada. Então aquilo aconteceu aqui, neste momento. Nós vemos a Estátua da Liberdade, o símbolo está aí, e então veio alguém e foi lá e trouxe o símbolo de volta à vida. De fato, ela foi lá e fez aquilo pelo que aquela estátua supostamente deveria significar. Admiro isso.

Sim, pois a Estátua da Liberdade é um monumento de boas vindas aos imigrantes.

Sim, ela não deveria ser um ponto turístico. Ela é trágica, é a luz.

Você gosta da estátua?

Ken Jacobs: Eu gosto dela porque uma garotinha que conhecemos gosta.

Flo Jacobs: Ela [a Estátua da Liberdade] é maravilhosa.

Ken Jacobs: Eu gosto dela. Não da escultura.

Flo Jacobs: Do interior.

Ken Jacobs: 0 interior tem uma engenharia maravilhosa, mas a parte exterior é... há uma palavra alemã...

Flo Jacobs: Kitsch.

Ken Jacobs: É kitsch!

Gostaria de lhe ouvir um pouco sobre a sua experiência como professor universitário. Você ensinou por muitos anos.

Me disseram que eu não poderia ensinar hoje em dia. Eu ofenderia muita gente.

Dossiê A Música e suas Determinações Materiais - $\underline{\text { https://revistaecopos.eco.ufrj.br/ }}$

ISSN 2175-8689 - v. 23, n. 1, 2020

DOI: 10.29146/eco-pos.v23i1.27547 
Por quê? 0 que acontecia nas suas aulas que hoje não seria mais aceitável?

Ken Jacobs: Eu falava de tudo. Nada era proibido. Não havia nada com que eu não pudesse lidar.

Flo Jacobs: Você devia falar do seu lema sobre assuntos delicados.

Ken Jacobs: Ah, claro! "Se é o assunto é delicado, nós o abordamos". [0 trocadilho se perde na tradução para o português. Em inglês: "If it's touchy, we touch it"]

Os alunos se sentiam intimidados na sua presença?

Alguns, sim. Mas outros se adaptavam e eu acho que eles desfrutavam do diálogo.

Os seus filmes testam a todo tempo a nossa experiência perceptiva habitual. Esse desejo de desafiar os hábitos do espectador se traduzia para a sua pedagogia em sala de aula?

Em sala de aula nós considerávamos tudo e eu queria que as coisas fossem realmente consideradas. 0 que estamos fazendo? 0 que estamos olhando? Com o que estamos lidando? As coisas são profundas se você as permite. Se você for com elas, elas o levarão a todo tipo de território proibido, e nós íamos.

Andei lendo sobre as suas aulas na Universidade de Binghamton. Adoro os títulos das suas disciplinas: "Filmes não são feitos no céu", "Ronald Reagan", "Estupidez inicial", "Estupidez intermediária", "Estupidez terminal". Adoraria ler essas ementas.

Nós estamos imersos em estupidez, não? Numa grande sopa de estupidez! Essas disciplinas tinham a ver com a, eu diria, extravagância da loucura de muitos filmes.

Segundo seus ex-alunos, nas suas aulas, documentários e filmes experimentais coexistiam com blockbusters como Independence Day (1996) e Gremlins 2 (1990). A academia costuma ignorar esse tipo de filme. Eles raramente são considerados a sério num ambiente universitário. Como você abordava esses filmes em sala de aula? Que tipo de debate eles estimulavam?

Dossiê A Música e suas Determinações Materiais - https://revistaecopos.eco.ufrj.br/

ISSN 2175-8689 - v. 23, n. 1, 2020

DOI: 10.29146/eco-pos.v23i1.27547 
Eles fazem a cabeça das pessoas. Se você está falando com alguém, você está falando com aquela porra daquele filme. Você deve realmente ver o filme e analisá-lo para entender aquela pessoa. 0 filme é a cabeça dela. Os filmes estão fazendo a cabeça das pessoas. As pessoas absorvem os filmes, eles não pensam sobre eles, elas simplesmente representam os filmes.

Então as suas aulas tinham sempre esse compromisso em debater o cinema mainstream.

Ken Jacobs: Sim, em absoluto.

Flo Jacobs: Ele se sentia obrigado a ver esses filmes até o momento em que se aposentou, então ele disse que enfim poderia se libertar deles.

Ken Jacobs: Há muito não vejo um filme de ação. Estou aposentado, já deu.

Flo Jacobs: Mas nós assistimos alguns filmes mainstream em 3D. Quais?

Ken Jacobs: Sim, vimos algumas coisas em 3D. Assistimos a um filme que era muito impressionante. Era um filme futurista, claro...

Flo Jacobs: Divertida Mente (2015)?

Ken Jacobs: Uau, Divertida Mente é brilhante! É realmente impressionante. Mas, hoje, o que poderia ser melhor do que se deitar na cama e assistir a um filme? Isto é, com uma TV com a tela grande o suficiente, maravilhosamente clara e nítida. É isso. Se um de nós quer ir ao banheiro, paramos o filme, vamos, voltamos, começamos o filme de novo. É super conveniente. Quem, hoje, pode ir ao cinema? Veja, é maravilhoso ver a tela grande, mas eu nunca partilhei do sentimento de rebanho do público. Eu nunca fiz parte da comunidade da sala de cinema ao assistir a um filme. Qualquer que fosse a reação [do público], ela não era contagiosa para mim. Eu estava à parte. Então isso [a TV] é bom, eu fico junto à minha melhor amiga aqui e nós vemos coisas incríveis. 
Mas, em geral, o que vocês assistem hoje em dia?

Flo me diz todas a noites: “O que você tem em preto e branco para hoje?”

\section{O que viram ontem?}

A Caixa de Pandora (1929), de Pabst. Incrível. Quer dizer, que habilidade, que habilidade expressiva.

Uma última pergunta: qual a sua memória mais remota? A memória mais antiga que você retém da sua infância?

Eu me lembro de deitar-me ao lado da minha mãe - essa área grande, quente, sólida: a minha mãe - e de ouvir a rua lá embaixo, no Brooklyn. A rua de paralelepípedos, os cavalos, as rodas de madeira, e elas faziam sons maravilhosos. Clop, Clop, Clop. Era lindo. E agora eu estou na era do computador! Como isso foi possível (risos)? 